\title{
The Occurrence of Non-Saccharomyces cerevisiae Yeast Species Over Three Vintages in Four Vineyards and Grape Musts From Four Production Regions of the Western Cape, South Africa*
}

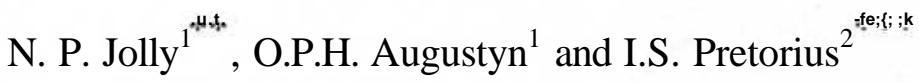 \\ (1) ARC Infruitec-Nietvoorbij, Private Bag X5026, 7599 Stellenbosch, South Africa \\ (2) Institute for Wine Biotechnology and Department of Viticulture \& Oenology, Stellenbosch University, Private Bag XI, 7602 Matieland \\ (Stellenbosch), South Africa
}

Submitted for publication: July 2002

Accepted for publication: May 2003

Key words: Non-Saccharomyces, yeasts, wine, fermentation

\begin{abstract}
The role of non-Saccharomyces yeasts in wine production has been extensively debated and there is growing evidence that non-Saccharomyces yeasts play an important role in wine quality. It has been suggested that metabolites formed by some non-Saccharomyces species may contribute to wine quality. Recently a comprehensive, longterm research programme was launched by role players in the South African wine industry, whose aims include the isolation, characterisation and preservation of the natural yeast biodiversity of the Western Cape. As part of the programme, this paper investigates the presence of non-Saccharomyces yeast species over three vintages in four vineyards and musts in four distinct areas of the Western Cape. Samples were taken and the non-Saccharomyces yeast isolates were characterised by biochemical profiling and pulse field gel electrophoresis. In total 720 yeasts representing 24 species were isolated. Predominant species found in the must samples, i.e. Candida stellata, Kloeckera apiculata, Candida pulcherrima and Candida colliculosa, should have the most impact on subsequent fermentation.
\end{abstract}

The role of non-Saccharomyces yeasts in wine production has been debated extensively. Earlier schools of thought referred to non-Saccharomyces yeasts as primarily spoilage organisms (Amerine \& Cruess, 1960; Van Zyl \& Du Plessis, 1961; Rankine, 1972; Le Roux et al., 1973). It was further accepted that they died during the initial stages of fermentation due to the toxicity of the rising alcohol concentration from the metabolism of Saccharomyces cerevisiae. Consequently, they were seen to be of little significance in wine production. Recently, the work of Fleet et al. (1984), Heard \& Fleet 1985), Longo et al. (1991), Todd (1995) and Gafner et al. (1996) showed that non-Saccharomyces yeasts survived during fermentation and could reach cell concentrations of $10^{6}$ to $10^{8}$ cells $/ \mathrm{mL}$. These numbers are similar to those reached by $S$. cerevisiae.

It has been suggested that metabolites formed by some nonSaccharomyces species may contribute to wine quality (Fleet et al, 1984; Gil et al, 1996; Lema et al, 1996; Soden et al, 2000). An example is glycerol production by Candida stellata (Ferraro et al, 2000) and ester production by Candida pulcherrima (Bisson \& Kunkee, 1991) that in some wines can have a positive influence on wine quality. Other species, such as Kloeckera apiculata, are associated with acetic acid production that can be detrimental to wine quality. However, large strain variability can be found among non-Saccharomyces species and not all strains with- in a particular species form high levels of oenologically negative compounds (Romano et al, 1992; Romano \& Suzzi, 1993). Some non-Saccharomyces species also possess P-glycosidase activity that can hydrolyse glycosically-bound aroma precursors (Todd, 1995). This supports the belief of winemakers, in especially the Old World wine regions, that indigenous yeasts impart a distinct regional and desired characteristic to their wines (Jackson, 1994).

The main sources of indigenous yeast flora in the must are the grapes and the equipment used to process the grapes (Peynaud \& Domercq, 1959; Rosini, 1984; Lonvaud-Funel, 1996). NonSaccharomyces yeasts are the dominant species on the grapes, but are found in lesser numbers in the cellar and on the cellar equipment (Vaughan-Martini \& Martini, 1995; Boulton et al, 1996; Constanti et al, 1997). At crushing, these yeasts can be introduced into the must.

The specific environmental conditions in the must, i.e. high osmotic pressure, the presence of $\mathrm{SO} 2$, the temperature and cellar hygiene, all play a role in determining which species can survive and grow in the must (Longo et al, 1991). However, in order to exploit the potential benefits and to minimise potential spoilage by undesired non-Saccharomyces yeasts, the oenologically important yeast populations on grapes and in must, as well as the effect of winemaking practices on these yeasts, should be known.

\footnotetext{
*This work was partially presented as a paper at the 23rd SASEV Congress, 18-19 November 1999, Somerset West and as a poster at the 2nd International SASEV Congress, 8-10 November 2000, Cape Town.

**Corresponding author: E-mail address: neil@infruit.agric.zja

${ }^{* * * *}$ Present address: The Australian Wine Research Institute, P.O. Box 197, Glen Osmond, Adelaide, SA5064, Australia.
}

Acknowledgements: The authors thank Winetechfor financial support, as well as the technical staffof the oenology group of the Post-Harvest \& Wine Technology Division of the ARC Infruitec-Nietvoorbij. 
This knowledge will help realise the predictions of Heard (1999) concerning the use of mixed yeast starter cultures tailored to reflect the characteristics of a given wine region.

The composition of vineyard and wine microflora in South Africa received attention in earlier work done by Du Plessis (1959), Van Zyl \& Du Plessis (1961) and Van Kerken (1963); however, it is unclear if any of these isolates have survived to the present. Recently, the distribution of indigenous $S$. cerevisiae yeasts in vineyards in the cooler, coastal and the warmer, inland regions of South Africa has been covered extensively by Van der Westhuizen et al. (2000a, 2000b) and Khan et al. (2000), respectively. These studies formed part of a comprehensive and ongoing long-term, collaborative research programme by ARC InfruitecNietvoorbij and Stellenbosch University. The programme's nine objectives were detailed by Pretorius et al. (1999). They include the isolation, characterisation and preservation of natural yeast biodiversity from the 350-year-old wine-producing regions of the Western Cape of South Africa; an investigation into the occurrence of area-specific indigenous yeasts and winery yeasts that impart a distinctive characteristic to wines from that area; and the evaluation of yeast isolates for continuous wine yeast selection and strain development programmes which have the ultimate aim of providing an appropriate yeast per cultivar, per area, per wine type. While the aforementioned is a daunting task, this study is the first to concentrate on the non-Sacchammyces group of yeasts. The aim of this study, as part of the above-mentioned programme, was to obtain an oenologically biased collection of nonSaccharomyces yeasts that could be used in future selection programmes for use in wine production. Concurrently, a broad overview of some of the non-Saccharomyces yeast species predominantly found in commercial vineyards and grape musts of the Western Cape, South Africa, could be obtained.

\section{MATERIALS AND METHODS}

\section{Areas sampled}

One Chardonnay vineyard and accompanying commercial cellar in each of four production areas was selected for sampling in three vintages, i.e. 1997, 1998 and 2000. The four vineyards and their respective cellars were in Constantia (cooler temperature zone), Stellenbosch and Slanghoek (intermediate temperature zone) and Robertson (warmer zone) (Fig. 1). These four areas were selected according to the climate classification of Le Roux (1974), as adapted by De Villiers (1997).

\section{Sample collection and yeast isolation}

Whole bunches of healthy Chardonnay grapes (1-2 kg per sampling point) were aseptically gathered over the whole vineyard from 10-15 vines (both the shaded and unshaded sides) the day before commercial harvesting, dropped directly into sterile plastic bags and transported to the laboratory in cool bags. At the laboratory the grapes were crushed by hand in the sealed bags. After thorough shaking, the bags were opened and the juice $(500 \mathrm{~mL})$ was poured into a sterile closed beaker and mixed (full speed on magnetic stirrer for $1 \mathrm{~min}$ ). One $\mathrm{mL}$ of juice was taken and a dilution series made in sterile $\mathrm{NaCl}(0.85 \%)$ solution and plated onto YPD agar (1\% yeast extract, $2 \%$ peptone, $2 \%$ glucose) with chloramphenicol $(0.1 \mathrm{mg} / \mathrm{L})$. Incubation was at $30^{\circ} \mathrm{C}$ for 5 days to allow colony formation. From count plates presenting between 30 and 300 colonies, 30 colonies were randomly selected. Selective lysine medium (Biolab, Merck), promoting the growth of yeasts other than $S$. cerevisiae, was used to ensure that no $S$. cerevisiae had been selected (Heard \& Fleet, 1986). The selected colonies were purified and stored at $4{ }^{\circ} \mathrm{C}$ until further analysis. Stock cultures were kept in glycerol at $-80^{\circ} \mathrm{C}$.

After commercial harvesting and processing of the grapes by the respective cellars, $500 \mathrm{~mL}$ samples of sedimented must were collected in sterile bottles. Isolation of the yeast then followed the same protocol as already described for the vineyard samples.

\section{Characterisation of yeast isolates}

The yeast isolates were characterised on the basis of biochemical profiles and pulse field gel electrophoresis.

\section{Biochemical profiles}

Biochemical profiles of each of the isolates were generated using the ID 32C AUX system (BioMérieux, France). Profiles were read after $48 \mathrm{~h}$ and the identity supplied by the database was used as a preliminary identity. If no identity could be assigned, a code number linked to the biochemical profile was given to the isolate.

Preparation of intact chromosomal DNA and puke field gel electrophoresis

Samples were prepared according to the embedded agarose procedure of Carle \& Olson (1985). Intact chromosomal DNA was separated using contour clamped homogenous electric field (CHEF) electrophoresis (CHEF-DR II, Bio-Rad Laboratories, Richmond, USA). All separations were carried out in $1 \%$ agarose gels (90 sec pulse for $15 \mathrm{~h} ; 120 \mathrm{sec}$ pulse for $20 \mathrm{~h}$, in TBE buffer at $\left.10^{\circ} \mathrm{C}\right)$. Gels were stained with ethidium bromide $(10 \mathrm{mg} / \mathrm{L})$, viewed on a trans-illuminator and then photographed.

A standard reference yeast ( $S$. cerevisiae strain Vin 13, Anchor Bio-Technologies, South Africa) was used on each CHEF gel, as three gels were needed to characterise the 30 isolates per sampling point. The banding pattern of each yeast isolate was digitised and compared to the others using a customised computer program (CHEF vl.4 @ T. Potgieter, ARC Infruitec-Nietvoorbij). This program allows DNA banding patterns to be digitised and stored in a database. Bands can then be compared to a specific pattern or all the patterns in the database.

\section{Grouping and identification of isolates}

The computer program, visual data (chromosomal banding patterns) and the biochemical profiles (identity or code number) were used to group yeasts. Identities supplied by the ID $32 \mathrm{C}$ system were noted. Subsequently, one representative yeast from each group was sent to a commercial laboratory (CBS, Delft, The Netherlands) for identification. That identification was then used as the identification for the other yeasts in the group.

\section{Meteorological data}

The monthly rainfall and average monthly maximum temperature (1996 to 2000) for the Constantia, Stellenbosch, Slanghoek and Robertson areas were obtained from Agromet (R. Wentzel, personal communication, 2001).

\section{RESULTS AND DISCUSSION}

\section{Sample areas and climatic conditions}

The four areas chosen for sampling represent four different climatic zones (Fig. 1). The Constantia area, the coolest, has a mean February temperature (MFT) (February being the harvest month) 


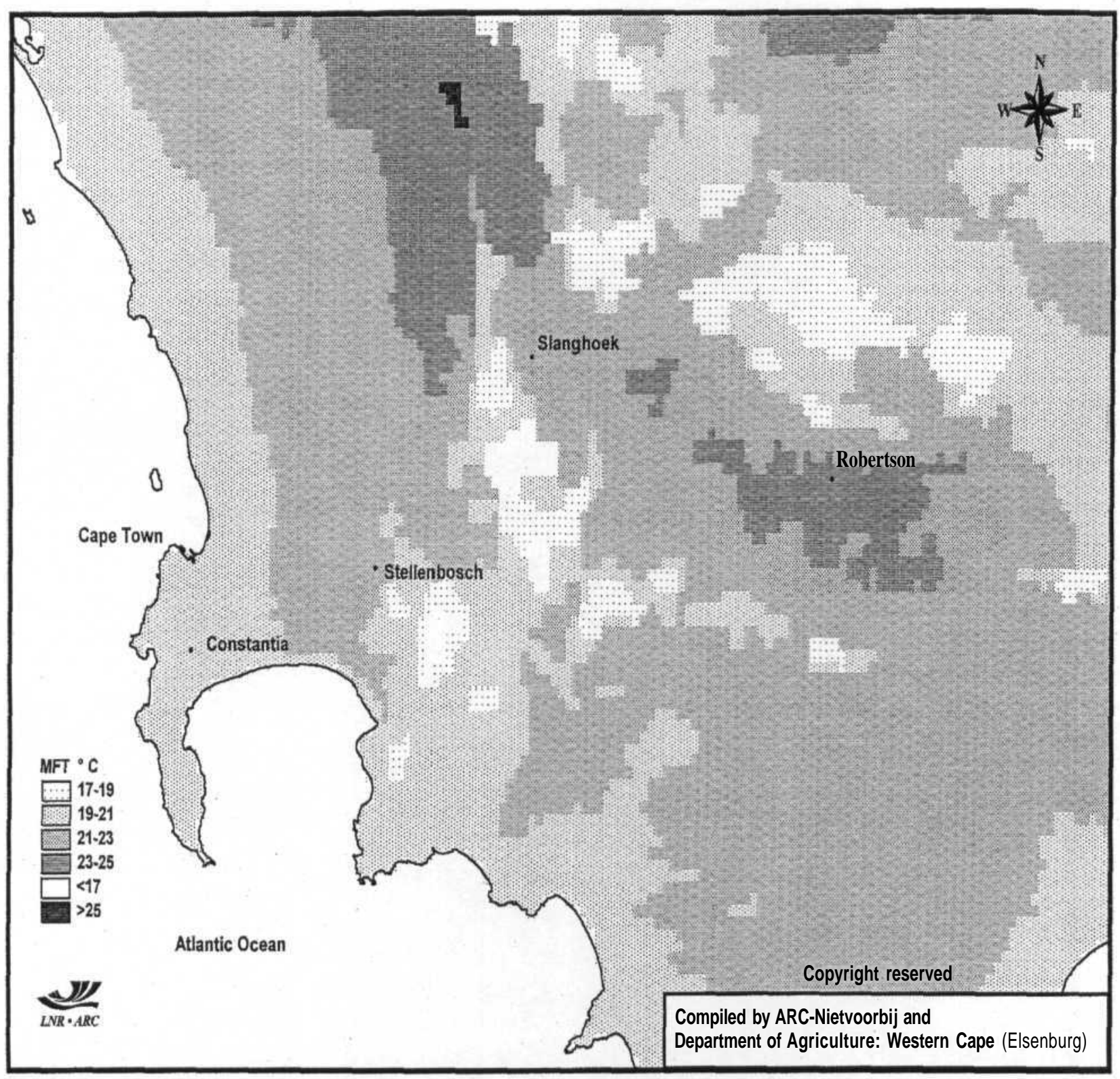

FIGURE1

Mean February temperature (MFT) for the production areas sampled in the Western Cape, South Africa.

of 19 to $21^{\circ} \mathrm{C}$ and is close to the Atlantic Ocean with its cooling sea breezes. The next area, Stellenbosch, is slightly wanner, with a MFT of 21 to $23^{\circ} \mathrm{C}$, but also has an open aspect towards the sea. The Slanghoek area has a similar MFT to Stellenbosch, but lies behind a range of mountains that blocks most of the maritime influence. The last area, Robertson, is the furthest inland and is the warmest area, with a MFT of 23 to $25^{\circ} \mathrm{C}$.

From heat summation data and rainfall figures, it is evident that the growing and pre-1997 harvest period (December 1996, January-February 1997) had more rain than usual, resulting in a cooler season (V. Bonnardot, personal communication, 2001). The pre-harvest period for 1998 showed less rainfall and was therefore warmer than normal. The pre-harvest period for 2000 was also warm and dry.

\section{Sample collection and yeast isolation}

Aseptic harvesting of the grapes and laboratory preparation of the must avoided contamination of samples by yeasts not present on the grapes. The must preparation technique used for the subsequent isolation of indigenous non-Sacchawmyces yeasts from the vineyard samples was considered adequate for the same reasons as laid out by Van der Westhuizen et al. (2000a) and Bisson \& Kunkee (1991). They argued that the more aggressive yeast recovery techniques, i.e. sonification of grapes as followed by Martini et al. (1980, 1996), while resulting in larger quantities of yeasts, did not lead to identification of any novel organisms, compared to milder sample preparation techniques. Our approach would furthermore clearly bias results towards yeast that would potentially have some oenological use. 
The cellar sample was taken after sedimentation to obtain a representation of vineyard yeasts carried over to the must, as well as yeasts resident on the cellar equipment and surfaces, but excluding any yeasts that normally would be removed during must clarification. The yeast population can change during this initial wine production phase (Mora \& Mulet, 1991). However, the remaining yeasts would be more tolerant to sulphur and osmotic pressure and would be the yeasts that play the biggest role in the subsequent fermentation phase.

The use of YPD agar plates incubated for five days ensured that slow-growing non-Saccharomyces yeasts could also grow, while the added antibiotic prevented any bacterial growth. The use of lysine media at this early stage could have suppressed slow-growing non-Saccharomyces yeasts, as well as S. cerevisiae. However, once the isolates had been selected, the non-Saccharomyces status was confirmed by the ability to grow on lysine medium and from electrophoretic karyotyping. Random selection of 30 colonies from the count plates (between 30 and 300 colonies) represents from $100 \%$ to only $10 \%$ of the possible isolates. While it is obvious that some minor species may have been overlooked on the plates with higher cell counts, the random selection ensured that predominant species were selected.

\section{Yeast characterisation and identification}

The use of the biochemical profiles and chromosomal banding patterns proved adequate for the grouping of similar species. However, the preliminary identification supplied by the ID $32 \mathrm{C}$ database was often incorrect. This was to be expected, as the system was designed for the identification of yeasts of clinical importance. However, correct identifications were obtained for K. apiculata, Candida colliculosa, Candida pelliculosa, Candida guilliermondii, Candida albicans and Rhodotorula spp. While not in the database, C. stellata gave a consistent profile, which was correlated to the identification supplied by CBS.

The yeasts identified by CBS were, where applicable, found to be the anamorphic form. Although the teleomorphic form may have been isolated originally, the yeasts had been kept in storage for some time before identification. This can result in a loss of sporulation (Yarrow, 1998; M. Th. Smith, personal communication, 2000).

\section{Non-Saccharomyces yeasts in vineyard samples}

The four vineyards that were investigated over three vintages represent 12 sampling points (samples). While this study was not an exhaustive survey, and one vineyard cannot be extrapolated to the whole area, it does give us some indication of the type of population dynamics that occurred. Grape microflora are affected by factors such as temperature, rainfall, humidity, vineyard altitude, insect vectors, vineyard spray regimes, nitrogen fertilisation practices, winery waste practices and the health of the grapes (Boulton et al., 1996). It therefore should be expected that different regions will show differences in the proportion of yeasts (Amerine et al., 1967; Longo et al., 1991). Varietal factors, e.g. thickness of grape skins, can also play a role (Bisson \& Kunkee, 1991). However, as only one cultivar was investigated, grape skin thickness can be disregarded in this investigation.

The total cell counts (Table 1 ) range from $1.6 \times 10^{3}$ to $1.2 \times 10^{6}$ cells $/ \mathrm{mL}$ and - apart from a slight reduction in average cell counts in 1998 (by a factor of 10) - showed no apparent correlation to weather patterns or climate. However, prior to the 1997 harvest, there was a severe outbreak of fungal diseases in the vineyards due to the cooler weather and rainfall. To combat this, heavy applications of chemical sprays were applied during the growing season. In the 1998 vintage chemical sprays were used again due to the high fungal spore load from the previous season. This has been suggested as a possible cause for reduced yeast presence on grapes (Parish \& Carroll, 1985; Van der Westhuizen et al., 2000a). However, preliminary work done by Sturm et al. (2002) showed that yeast species biodiversity was not influenced by pest and disease management practices (integrated pest management, organic farming, application of antagonistic bacteria and copper applications). In contrast, Cabras et al. (1999) showed that certain pesticides can stimulate yeasts such as $K$. apiculata.

The number of non-Saccharomyces species isolated in each sample ranged from one to four, with the exception of Stellenbosch, where eight species were isolated in 1997 (Table 2). There appears to be no pattern relating to weather and climatic conditions. In total, 15 species were isolated in this study. In a comparative study, regarding method of yeast isolation, Yanigida et al. (1992) isolated 12 species. Direct comparison with other studies is difficult as different approaches for yeast isolation were followed. In the previous South African investigation of 1961 (Van Zyl \& Du Plessis, 1961) 15 species of non-Saccharomyces were also isolated. However, their approach entailed incubating berries in sterile grape juice until growth was observed. Studies in other parts of the world found between nine and 12 species (Parish \& Carroll, 1985; Yanagida et al, 1992).

Single species predominance ( $>50 \%$ of isolates) occurred in 11 of the samples. No single species predominated in the twelfth sample. The species that had the highest incidence of predominance was $K$. apiculata, although in only five of the 12 samples. This scenario was also reported by Yanagida et al. (1992), who found $K$. apiculata predominance in only six of 11 sites. In the earlier study of South African vineyards (Van Zyl \& Du Plessis, 1961), K. apiculata was listed as the most frequent; however, as already mentioned, their methodology would have played a role. Smaller numbers of $K$. apiculata were isolated in a further three samples in this study. However, it was absent in all three Robertson samples. In Constantia there appeared to be a tendency towards declining numbers of $K$. apiculata over the three vin-

\section{TABLE 1}

Total cell counts of non-Saccharomyces yeasts over three vintages in four Chardonnay vineyards in the Western Cape, South Africa.

\begin{tabular}{lcccc}
\hline Vineyard & \multicolumn{5}{c}{ Total cell count (cells/mL) } \\
\hline \multicolumn{5}{c}{ Vintage } \\
\hline & $\mathbf{1 9 9 7}$ & $\mathbf{1 9 9 8}$ & 2000 & Average \\
\hline Constantia & $1.2 \times 10^{5}$ & $8.0 \times 10^{4}$ & $8.9 \times 10^{5}$ & $3.6 \times 10^{5}$ \\
Stellenbosch & $1.2 \times 10^{6}$ & $5.8 \times 10^{4}$ & $1.6 \times 10^{3}$ & $4.2 \times 10^{5}$ \\
Slanghoek & $1.4 \times 10^{5}$ & $8.6 \times 10^{4}$ & $1.4 \times 10^{5}$ & $1.2 \times 10^{5}$ \\
Robertson & $8.7 \times 10^{4}$ & $1.1 \times 10^{5}$ & $1.7 \times 10^{4}$ & $7.1 \times 10^{4}$ \\
\hline $\begin{array}{l}\text { Average total cell count } \\
\text { (cells/mL) for each vintage }\end{array}$ & $3.9 \times \mathbf{1 0}^{\mathbf{5}}$ & $8.4 \times 10^{4}$ & $2.6 \times 105$ & - \\
\hline
\end{tabular}


tages studied, while in Stellenbosch and Slanghoek there was an initial decline followed by an increase in cell numbers.

In three of the remaining six samples $C$. pulcherrima was the most frequently found yeast. This yeast was reported by Van Zyl \& Du Plessis (1961) to be the fourth most frequent in their study.

Other yeasts that dominated in single samples only were Kluyveromyces thermotolerans, a Rhodotorula sp. andZygosaccharomyces bailii. $K$. thermotolerans has been isolated from grape must sampled in the cellar (Torija et al., 2001), but not from vineyards. Rhodotorula spp. were also reported by Van Zyl \& Du Plessis (1961) and Parish \& Carroll (1985) in vineyards and on grape berry surfaces, but not in predominant numbers. Z. bailii has been reported (Peynaud \& Domercq, 1959), but it is usually associated with wine spoilage (Sponholz, 1993). However, as far as the authors can ascertain, this yeast has not been reported as predominant in vineyards.

The emergence and disappearance of some of the species over the four years may be coupled to the colonisation of bunches by specific yeasts (Peynaud \& Domercq, 1959; Török et al., 1996). During randomised sampling colonised bunches might have been missed. Vineyard practices with resultant physical and micro-climatic changes could also have played a role.

In the Robertson sample of 2000 a large percentage (47\%) of the pathogenic yeast $C$. albicans was isolated. This is not the first time that $C$. albicans has been isolated from grapes (Parish \& Carroll, 1985). However, due to taxonomic changes, yeasts such as Candida stellatoidea, previously reported in vineyards (grape vine flowers) have been reclassified to the $C$. albicans species (Meyer et al., 1998).
Non-Saccharomyces yeasts in must

Non-Saccharomyces yeasts found on grapes and cellar equipment are carried over to the must during crushing (Peynaud \& Domercq, 1959; Bisson \& Kunkee, 1991; Lonvaud-Funel, 1996). The specific must environment, i.e. low $\mathrm{pH}$, high sugar content (high osmotic pressure), the presence of $\mathrm{SO} 2$ added at crushing and temperature, plays a role in determining which species of yeasts can survive and grow (Bisson \& Kunkee, 1991; Longo et al., 1991). In addition, the method of harvesting (hand vs. mechanical), grape temperature, method and time of transport to cellar, time lapse before crushing, method of processing (whole bunches vs. crushing) and methods of clarification also play an important role in determining what yeast will be present in the clarified must (Fleet, 1990; Mora \& Mulet, 1991; Epifanio et al., 1999; Pretorius 2000). From a winemaking point of view, it is important to know what non-Saccharomyces yeasts can survive and grow in must, as they are the ones that will have the most influence on wine quality.

In this study the vineyards were all commercial blocks with differing methods of harvest beyond the control of the authors. The Constantia, Stellenbosch and Robertson vineyards were harvested by hand, while the Slanghoek vineyard was machine harvested. These differences and the time taken to process the grapes can allow the yeast population to increase (Peynaud \& Domercq, 1959). This makes actual comparisons between musts from the different cellars difficult.

The total number of cells in each must sample varied from $8.6 \times 10^{3}$ to $5.2 \times 10^{6}$ cells $/ \mathrm{mL}$ (Table 3 ). On average the cell counts were higher in the cellar samples than in the vineyard samples. This

\section{TABLE 2}

Seasonal variation in non-Saccharomyces yeasts over three vintages in four Chardonnay vineyards in the Western Cape, South Africa.

Percentage isolates $(\%)$

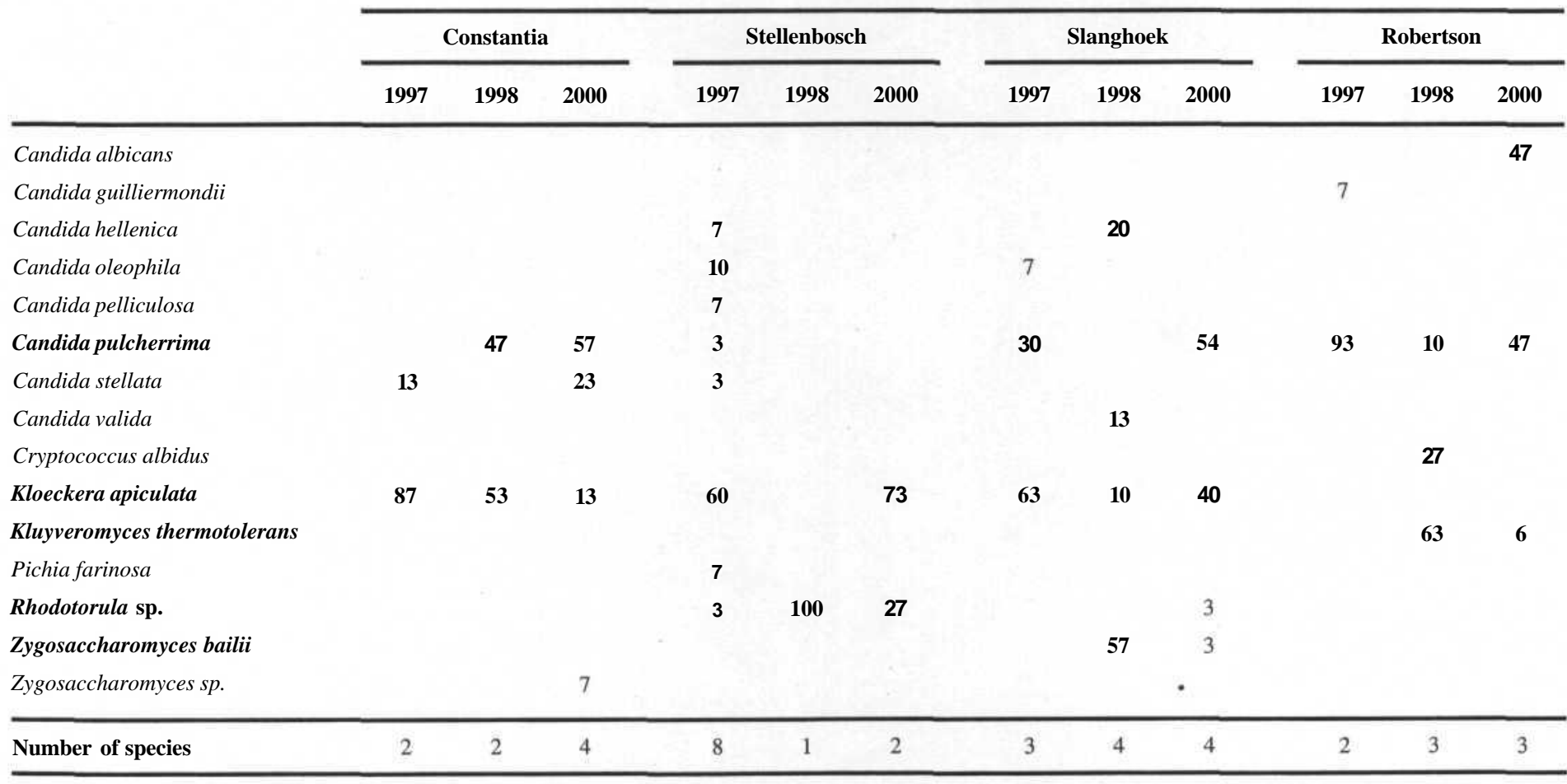

${ }^{1}$ Dominant yeast $(>50 \%)$ indicated in bold type. 
may be due to the longer time that the yeasts were exposed to the nutrients in the must. It is also an indication that some of the nonSaccharomyces yeasts are not as sensitive to $\mathrm{SO} 2$ as is generally assumed. The diversity of yeasts was very similar to the vineyard samples (three to eight species per sample) (Table 4). The exception was Robertson (1998), where only one group was isolated. This is comparable to other studies, where the total number of species isolated varied from two to 27 (Peynaud \& Domercq, 1959;

\section{TABLE 3}

Total cell counts of non-Saccharomyces yeasts over three vintages in four Chardonnay musts in the Western Cape, South Africa.

\begin{tabular}{lcccc}
\hline Vineyard & \multicolumn{5}{c}{ Total cell count (cells/mL) } \\
\hline \multicolumn{5}{c}{ Vintage } \\
\hline & $\mathbf{1 9 9 7}$ & $\mathbf{1 9 9 8}$ & 2000 & Average \\
\hline Constantia & $2.6 \times 10^{6}$ & $7.8 \times 10^{5}$ & $5.2 \times 10^{6}$ & $2.9 \times 10^{6}$ \\
$\begin{array}{l}\text { Stellenbosch } \\
\text { Slanghoek }\end{array}$ & $1.6 \times 10^{5}$ & $4.2 \times 10^{4}$ & $8.6 \times 10^{3}$ & $7.0 \times 10^{4}$ \\
Robertson & $1.5 \times 10^{5}$ & $8.3 \times 10^{5}$ & $3.0 \times 10^{5}$ & $4.3 \times 10^{5}$ \\
\hline $\begin{array}{l}\text { Average total cell count } \\
\text { (cells/mL) for each vintage }\end{array}$ & $7.3 \times 10^{5}$ & $1.2 \times 10^{6}$ & $1.4 \times 10^{6}$ & - \\
\hline
\end{tabular}

Fleet et al, 1984; Parish \& Carroll, 1985; Mora \& Mulet, 1991; Longo et al, 1991; Schiitz \& Gafner, 1993; Constanti et al, 1997).

Predominance by four yeast species was found in eight samples. They were $C$. stellata (four samples), K. apiculata (two samples), C. colliculosa (one sample) and C. pulcherrima (one sample). Another species found in high numbers was $C$. guilliermondii (43\%) in Robertson 2000.

C. stellata (Constanti et al, 1997; Torija et al, 2001) and $K$. apiculata (Constanti et al, 1997) have previously been reported as predominant at the start of wine fermentation. However, Van Zyl \& Du Plessis (1961) found low numbers of Kloeckera sp. during their investigation. They attributed this to the high levels of $\mathrm{SO}_{2}$ used to aid settling. Modern cellars tend to use less $\mathrm{SO}_{2}$, enabling a higher proportion of non-Saccharomyces yeasts to survive. C. colliculosa has also previously been reported as predominant in grape must (Heard \& Fleet, 1985; Torija et al., 2001) but not C. pulcherrima (Bisson \& Kunkee, 1991; Longo et al, 1991; Torija et al, 2001).

The isolation of Rhodotorula sp. (7\%) in Stellenbosch (2000) is unusual and is not in accordance to its non-fermentative metabolism (Longo et al, 1991). However, Rhodotorula spp. grow very slowly on normal YPD agar and its presence may easily be overlooked due to the rapid growth of other yeasts. It would be expected that its numbers would decline very quickly once fermentation commenced, as this yeast is very sensitive to ethanol.

TABLE 4

Distribution of non-Saccharomyces yeasts in four Chardonnay musts over three vintages from four cellars in the Western Cape, South Africa.

Percentage $(\%)$ isolates (out of 30)

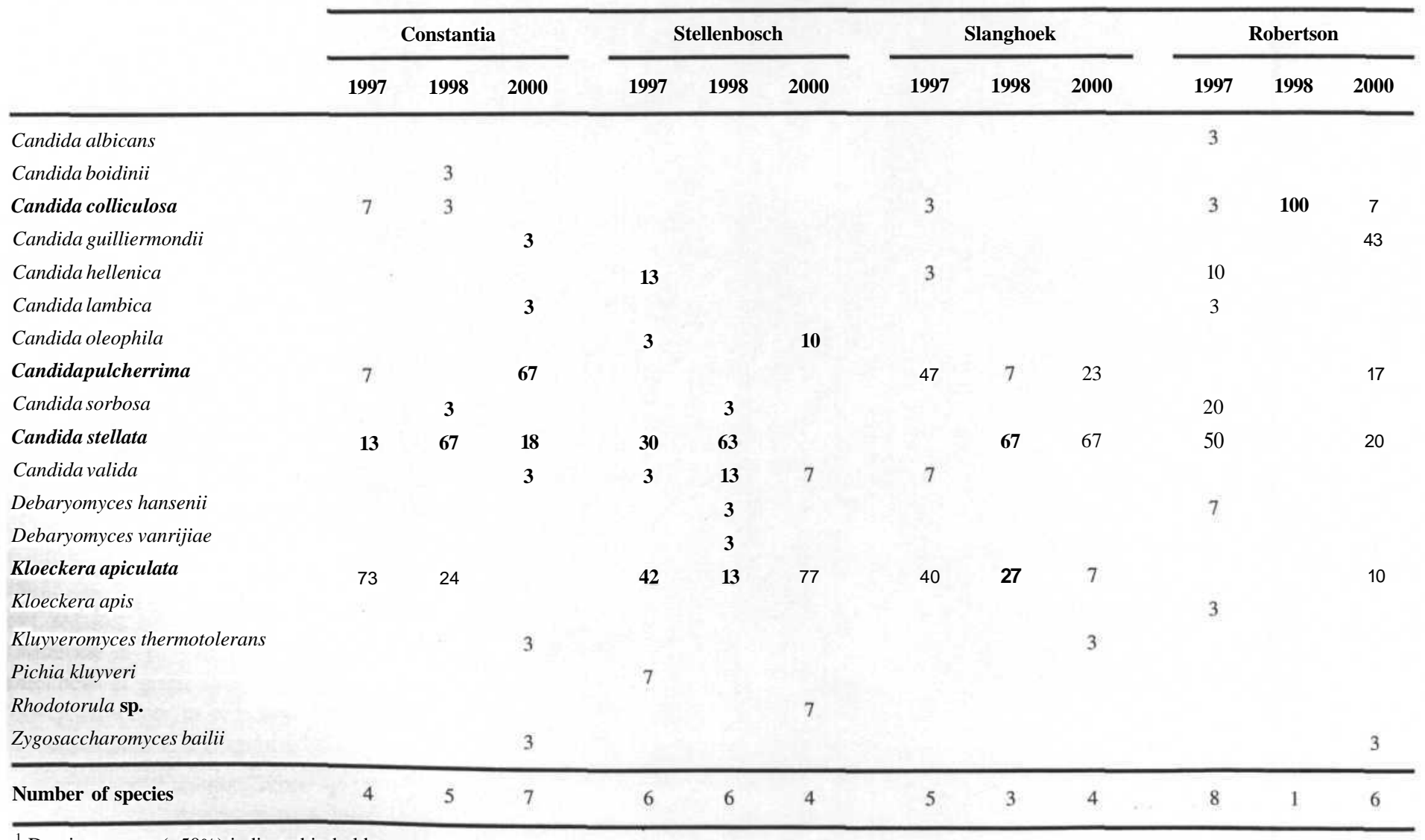

${ }^{1}$ Dominant yeast $(>50 \%)$ indicated in bold type. 


\section{General comparison of vineyard and cellar isolates}

Geographic location and weather patterns, while obviously impacting on non-Saccharomyces populations, are difficult to correlate with specific patterns in yeast population. Furthermore, the cellar processes and environment play an important role in determining the non-Saccharomyces population in must. Variations did occur in species diversity and numbers, and a small number of non-Saccharomyces yeasts tended to dominate in vineyards and must, but not in all the samples studied.

Generally there was a greater diversity of yeasts in the processed must than from the vineyard samples (Tables $2 \& 4$ ). While in some instances the must population contained yeasts also found in the vineyard, this was not always the case (e.g. Robertson in 1997 and 1998). The broader diversity of yeasts in the must may be due to yeasts obtained from the production equipment during grape processing. The yeasts in the must may also have been on the surface of the grapes in very low numbers and therefore were not isolated. During the subsequent crushing and settling, they could have multiplied to such an extent that they could be detected. Other species found in the vineyard, but not in the must, may have been unable to survive in the higher osmotic pressure of the must or may have been sensitive to $\mathrm{SO}_{2}$ added to the must.

As can be seen from the data presented, it would be unwise to predict the indigenous non-Saccharomyces yeast must population purely from a limited study of the grapes in the vineyard. Obvious factors, such as the method of harvest, transportation to the cellar and subsequent processing techniques, will all impact on the nonSaccharomyces population. Added to this is the indigenous cellar population and enrichment of yeasts during the sedimentation and pre-alcoholic fermentation phase. The non-Saccharomyces yeasts that are finally represented in the clarified must will therefore be those most tolerant to the existing conditions in the must and will be in the best position to continue their growth and have an oenological impact on wine fermentation. The predominant yeasts may be expected to have the most effect on the subsequent wine fermentation and resultant wine quality. $K$. apiculata can form high levels of volatile acidity; however, not all strains carry this trait and other metabolites can have a positive contribution (Romano et al, 1992; Romano \& Suzzi, 1993). Glycerol production by $C$. stellata has already been employed for the improvement of the analytical quality of wine (Ciani \& Ferraro, 1998; Ferraro et al., 2000), while C. pulcherrima is known to produce high amounts of esters (Bisson \& Kunkee, 1991). Esters can make a positive contribution to young wines with few cultivar characteristics.

\section{CONCLUSIONS}

As part of the broader programme previously mentioned, this study was successful in isolating and preserving an oenologically biased range of non-Saccharomyces yeasts found in South African vineyards and musts. In total this collection represents 24 different species, comprised of 720 yeast isolates. Of these, nine species predominated in the various samples investigated. Furthermore, each sampling point had a different yeast population, but no pattern linking species to climatic zone was observed. Four of the predominant species, i.e. C. colliculosa, C. pulcherri$m a, C$. stellata and $K$. apiculata, were found in the grape must.
These species could therefore be expected to have the biggest impact on wine quality and their contribution should receive further attention. In addition, the affect of different winemaking parameters on these yeasts should also be investigated so that conditions favouring their growth can be maintained.

\section{LITERATURE CITED}

Amerine, MA. \& Cruess, W.V., 1960. The technology of wine making. The AVI Publishing Company, Inc, Westport, Connecticut.

Amerine, M.A., Berg, H.W. \& Cruess, W.V., 1967. The technology of wine making, second edition. The AVI Publishing Company, Inc., Connecticut.

Bisson, L.F. \& Kunkee, R.E., 1991. Microbial interactions during wine production. In: Zeikus, J.G. \& Johnson, E.A. (eds). Mixed cultures in biotechnology, McGraw-Hill, Inc., New York. pp. 39-68.

Boulton, R.B., Singleton, V.L., Bisson, L.F. \& Kunkee, R.E., 1996. Principles and practices of winemaking. Chapman \& Hall, New York.

Cabras, P., Angioni, A., Garau, V.L., Pirisi, F.M., Farris, G.A., Madau, G. \& Emonti, G., 1999. Pesticides in fermentative processes of wine. J. Agric. Food Chem. 47, 3854-3857.

Carle, G.F. \& Olson, M.V., 1985. An electrophoretic karyotype for yeast. Proc. Natl. Acad. Sci. USA. 82, 3756-3760.

Ciani, M. \& Ferraro, L., 1998. Combined use of immobilized Candida stellata cells and Saccharomyces cerevisiae to improve the quality of wines. J. Appl. Microbiol. 85, 247-54.

Constanti, M., Poblet, M., Arola, L., Mas, A. \& Guillamon, M., 1997. Analysis of yeast populations during alcoholic fermentation in a newly established winery. Am. J. Enol. Vitic. 48, 339-344.

De Villiers, F., 1997. The use of geographic information systems (GIS) in the selection of wine cultivars for specific areas by using temperature climatic models. 22nd OIV Congress of the Vine and Wine, 1 -5 December 1997, Buenos Aires, Argentina

Du Plessis, L. de W., 1959. A study of micro-organisms associated with the flowers and ripening berries of a number of grape varieties (in Afrikaans). Thesis. Stellenbosch University, Private Bag XI, 7602 Matieland (Stellenbosch), South Africa.

Epifanio, S.I., Gutierrez, A.R., Santamaria, M.P. \& López, R., 1999. The influence of enological practices on the selection of wild yeast strains in spontaneous fermentation. Am. J. Enol. Vitic. 50, 219-224.

Ferraro, L., Fatichenti, F. \& Ciani, M., 2000. Pilot scale vinification process using immobilized Candida stellata cells and Saccharomyces cerevisiae. Proc. Biochem. 35, 1125-1129.

Fleet, G.H., Lafon-Lafourcade, S. \& Ribéreau-Gayon, P., 1984. Evolution of yeasts and lactic acid bacteria during fermentation and storage of Bordeaux wines. App. Environ. Microbiol. 48, 1034-1038.

Fleet, G.H., 1990. Which yeast species really conducts the fermentation? In: Williams, P.J., Davidson, D.M., Lee, T.H. (eds). Proc. 7th Aust. Wine Ind. Tech. Conf., 13-17 August 1989, Wine Research Institute Winetitles, Adelaide, Australia, pp. 153-156

Gafner, J., Hoffmann, P., Schiitz, M. \& Iselin, F., 1996. Changes of the yeast microflora in the vineyard and during the fermentation. In: Lemperle, E., Trogus, H. \& Figlestahler, P. (eds). Proc. 11th Int. Oenol. Symp., Sopron, Hungary, 3-5 June 1996. pp. 42-54.

Gil, J.V., Mateo, J.J., Jimenez, M., Pastor, A. \& Huerta, T., 1996. Aroma compounds in wines as influenced by apiculate yeasts. J. Food Sci. 61, 1247-1249, 1266.

Heard, G.M. \& Fleet, G.H., 1985, Growth of natural yeast flora during the fermentation of inoculated wines. Appl. Environ. Microbiol. 50, 727-728.

Heard, G.M. \& Fleet, G.H., 1986. Evaluation of selective media for enumeration of yeasts during wine fermentation. J.Appl. Bact. 60,477-481.

Heard, G., 1999. Novel yeasts in winemaking — looking to the future. Food Aus. $51,347-352$.

Jackson, R.S., 1994. Wine Science - principles and applications. Academic Press, San Diego.

Khan, W., Augustyn, O.P.H., Van der Westhuizen, T.J., Lambrechts, M.G. \& Pretorius, I.S., 2000. Geographic distribution and evaluation of Saccharomyces cerevisiae strains isolated from the vineyards in the warmer, inland regions of the Western Cape in South Africa. S. Afr. J. Enol. Vitic. 21, 17-31. 
Kurtzman, C.P. \& Fell, J.W., 1998. Definition, clasification and nomenclature of the yeasts. In: Kurtzman, C.P. \& Fell, J.W. (eds). The yeasts, a taxonomic study, Elsevier, Amsterdam, pp. 3-5.

Le Roux, G., Eschenbruch, R. \& De Bruin, S.I., 1973. The microbiology of South African wine-making. Part VIII. The microflora of healthy and Botrytis cinerea infected grapes. Phytophylactica 5, 51-54.

Le Roux, E.G., 1974. 'n Klimaatsindeling van die Suidwes-Kaaplandse wynbougebiede (In Afrikaans). Thesis, Stellenbosch University, Private Bag XI, 7602 Matieland (Stellenbosch), South Africa. *

Lema, C, Garcia-Jares, C, Orriols, I. \& Angulo. L., 1996. Contribution of Saccharomyces and non-Saccharomyces populations to the production of some components of Albarifio wine aroma. Am. J. Enol. Vitic. 47, 206-216.

Longo, E., Cansado, J., Agrelo, D. \& Villa, T.G., 1991. Effect of climatic conditions on yeast diversity in grape musts from Northwest Spain. Am. J. Enol. Vitic. $42,141-144$.

Lonvaud-Funel, A., 1996. Microorganisms of winemaking. Cerevisia: Belgian I. Brew. Biotechnol. 21, 55-58.

Martini, A., Frederici, F. \& Rosini, G., 1980. A new approach to the study of yeast ecology of natural substances. Can. J. Microbiol. 26, 856-859.

Martini, A., Ciani, M. \& Scorzetti, G., 1996. Direct enumeration and isolation of wine yeasts from grape surfaces. Am. J. Enol. Vitic. 47, 435-440.

Meyer, S.A., Payne, R.W. \& Yarrow, D., 1998. Candida Berkhout. In: Kurtzman, C.P. \& Fell, J.W. (eds). The yeasts, a taxonomic study, Elsevier Science BV, Amsterdam, pp. 454-573.

Mora, J. \& Mulet, A., 1991. Effects of some treatments of grape juice on the population and growth of yeast species during fermentation. Am. J. Enol. Vitic. 42, 133-136.

Parish, M.E. \& Caroll, D.E., 1985. Indigenous yeasts associated with Muscadine (Vitis rotundifolia) grapes and musts. Am.J.Enol.Vitic. 36, 165-169.

Peynaud, E. \& Domercq, S., 1959. A review of microbiological problems in winemaking in France. Am. J. Enol. Vitic. 10, 69-77.

Pretorius, I.S., Van der Westhuizen, T.J. \& Augustyn, O.P.H., 1999. Yeast biodiversity in vineyards and wineries and its importance to the South African wine industry - a review. S. Afr. J. Enol. Vitic. 20, 61-74.

Pretorius, I.S., 2000. Tailoring wine yeast for the new millennium: novel approaches to the ancient art of winemaking. Yeast 16, 675-729.

Rankine, B.C., 1972. Influence of yeast strain and malo-lactic fermentation on composition and quality of table wines. A. J. Enol. Vitic. 23, 152-158.

Romano, P., Suzzi, G., Comi, G. \& Zironi, R., 1992. Higher alcohol and acetic acid production by apiculate wine yeasts. J. Appl. Bact. 73, 126-130.

Romano, P. \& Suzzi, G., 1993. Potential use for Zygosaccharomyces species in winemaking. J. Wine Res. 4, 87-94.
Rosini, G., 1984. Assessment of dominance of added yeast in wine fermentation and origin of Saccharomyces cerevisiae in wine-making. J. Gen. Appl. Microbiol. $30,249-256$

Schiitz, M. \& Gafner, J., 1993. Analysis of yeast diversity during spontaneous and induced alcoholic fermentations. J. App. Bacteriol. 75, 551-558.

Soden, A., Francis, L., Gockowiak, H., Lee, T. \& Henschke, P., 2000. Complexing wine flavour with indigenous non-Saccharomyces wine yeasts. 5th Int. Symp. Cool Climate Vitic. and Oenol., 16-20 January 2000, Melbourne, Australia.

Sponholz, W.-R., 1993. Wine spoilage by microorganisms. In: Fleet, G.H. (ed.). Wine microbiology and biotechnology, Harwood Academic Publishers, pp. 395-420.

Sturm, J., Rauhut, D., Grossmann, M., Dorn, C. \& Berkelmann-Loehnertz, B., 2002. Studies on indigenous yeast populations of grape berry surfaces (Vitis vinifera L.). (Poster presentation ). 22nd International Specialised Symposium on Yeasts, 25-28 March 2002, Pilanesberg National Park, South Africa.

Todd, B.E.N., 1995. Enhancing the sensory properties of wine using p-glycosidase activity of wine micro-organisms. Aust. Grape Winemaker 382, 22-23.

Torija, M.J., Rozés, N., Poblet, M., Guillamon, J.M. \& Mas, A., 2001. Yeast population dynamics in spontaneous fermentations: Comparison between two different wine-producing areas over a period of three years. A. van Leeuw. 79, 345-352.

Törơk, T., Mortimer, R.K., Romano, P., Suzzi, G. \& Polsinelli, M., 1996. Quest for wine yeasts - an old story revisited. J. Indust. Microbiol. 17, 303-313.

Van der Westhuizen, T.J., Augustyn, O.P.H. \& Pretorius, I.S., 2000a. Geographical distribution of indigenous Saccharomyces cerevisiae strains isolated from vineyards in the coastal regions of the Western Cape in South Africa. S. Afr. J. Enol. Vitic. 21, 3-9.

Van der Westhuizen, T.J., Augustyn, O.P.H., Khan, W. \& Pretorius, I.S., 2000b. Seasonal variation of indigenous Saccharomyces cerevisiae strains isolated from vineyards of the Western Cape in South Africa. S. Afr. J. Enol. Vitic. 21, 10-16.

Van Kerken, A.E., 1963. Contribution to the ecology of yeasts occurring in wine. $\mathrm{PhD}$ dissertation, University of the Orange Free State, Bloemfontein, South Africa.

Van Zyl, J.A. \& Du Plessis, L. de W., 1961. The microbiology of South African winemaking. Part I. The yeasts occurring in vineyards, must and wines. S. A. J. Agric. Sci. 4, 393-403

Vaughan-Martini, A. \& Martini, A., 1995. Facts, myths and legends on the prime industrial microorganism. J. Indust. Microbiol. 14, 514-522.

Yanagida, F., Ichinose, F., Shinohara, T. \& Goto, S., 1992. Distribution of wild yeasts in the white grape varieties at central Japan. J. Gen. Appl. Microbiol. 38, 501-504.

Yarrow, D., 1998. Methods for the isolation, maintenance and identification of yeasts. In: Kurtzman, C.P. \& Fell, J.W. (eds). The yeasts, a taxonomic study, Elsevier, Amsterdam, pp. 77-100. 